\title{
SUPPLEMENT TO THE \\ UMTRA PROJECT WATER SAMPLING AND ANALYSIS PLAN \\ MAYBELL, COLORADO
}

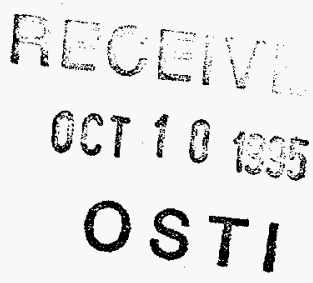

September 1995

Prepared for

U.S. Department of Energy

Environmental Restoration Division

UMTRA Project Team

Albuquerque, New Mexico

Prepared by

Jacobs Engineering Group Inc.

Albuquerque, New Mexico

DISTRIBUTION OF THIS DOCUMENT IS UNLIMITEB

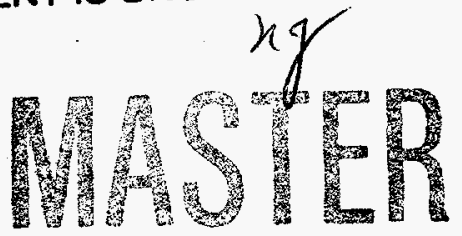




\section{DISCLAIMER}

This report was prepared as an account of work sponsored by an agency of the United States Government. Neither the United States Government nor any agency thereof, nor any of their employees, make any warranty, express or implied, or assumes any legal liability or responsibility for the accuracy, completeness, or usefulness of any information, apparatus, product, or process disclosed, or represents that its use would not infringe privately owned rights. Reference herein to any specific commercial product, process, or service by trade name, trademark, manufacturer, or otherwise does not necessarily constitute or imply its endorsement, recommendation, or favoring by the United States Government or any agency thereof. The views and

opinions of authors expressed herein do not necessarily state or reflect those of the United States Government or any agency thereof. 


\section{DISCLAIMER}

Portions of this document may be illegible in electronic image products. Images are produced from the best available original document. 


\subsection{INTRODUCTION}

This water sampling and analysis plan (WSAP) supplement supports the regulatory and technical basis for water sampling at the Maybell, Colorado, Uranium Mill Tailings Remedial Action (UMTRA) Project site, as defined in the 1994 WSAP document for Maybell (DOE, 1994a). Further, this supplement serves to confirm our present understanding of the site relative to the hydrogeology and contaminant distribution as well as our intention to continue to use the sampling strategy as presented in the 1994 WSAP document for Maybell.

\subsection{GROUND WATER AND SURFACE WATER MONITORING}

Ground water and surface water monitoring activities are derived from the U.S. Environmental Protection Agency regulations in 40 CFR Part 192 (1994) and 60 CFR 2854 (1995). Sampling procedures are guided by the UMTRA Project standard operating procedures (JEG, n.d.), the Technical Approach Document (DOE, 1989), and the most effective technical approach for the site. Additional site-specific documents relevant to the Maybell site are the Maybell Baseline Risk Assessment (currently in progress), the Maybell Remedial Action Plan (RAP) (DOE, 1994b), and the Maybell Environmental Assessment (DOE, 1995).

\subsection{SAMPLING PLAN}

The sampling plan, as described in the 1994 WSAP, is to continue annual monitoring of the site ground and surface water to continue to evaluate site characteristics and water quality changes, to monitor potential changes in ground water quality due to surface remediation activities, and to comply with requirements in the RAP. In addition to annual sampling, ground water samples will be collected semiannually from monitor wells situated at the southwest edge of the tailings pile. This pattern of sampling every six months will continue for two years, at which time sampling results will be reviewed to determine if a lesser or greater amount of sampling and analysis is warranted. Sampling was conducted at the Maybell site in March/April and September 1995. A supplemental round of sampling of four surface water locations and one well was conducted in June 1995.

The next round of sampling should be conducted in April 1996 and will include the following wells and surface locations that are to be sampled on an annual basis:

- Background wells (602 and 660) (Figure 1).

- Wells along southwest edge of tailings pile (604, 645, 695 and 696).

- Wells that might be impacted by transient drainage from the tailings pile $(667,676$, $663,609,666$, and 668).

- Surface location (718, Rob Pit) (Figure 2). 
Monitor wells to be sampled semiannually are the wells along the southwest edge of the tailings pile $(604,645,695$ and 696).

The following constituents will be analyzed for: calcium, chloride, copper, iron, fluoride, magnesium, manganese, nitrate, phosphate, potassium, selenium, sodium, strontium, sulfate, and uranium. Field analyses will be conducted for alkalinity, dissolved oxygen, oxidation/reduction potential, pH, specific conductance, and temperature.

\subsection{REFERENCES}

DOE (U.S. Department of Energy), 1995. Environmental Assessment of Remedial Action at the Maybell Uranium Mill Tailings Site Near Maybell, Colorado, final, UMTRADOE/EA-0347 Rev. 2, prepared by the U.S. Department of Energy, UMTRA Project Office, Albuquerque Operations Office, Albuquerque, New Mexico, January, 1995.

DOE (U.S. Department of Energy), 1994a. UMTRA Project Water Sampling and Analysis Plan Maybell, Colorado, final, UMTRA-DOE/AL 62350-125, prepared by the U.S. Department of Energy, UMTRA Project Office, Albuquerque Operations Office, Albuquerque, New Mexico, June, 1994.

DOE (U.S. Department of Energy), 1994b. Remedial Action Plan and Site Design for Stabilization of the Inactive Uranium Mill Tailings Site at Maybell, Colorado, final, UMTRA-DOE/AL-62350.24F Rev. 0, prepared by the U.S. Department of Energy, UMTRA Project Office, Albuquerque Operations Office, Albuquerque, New Mexico, June, 1994.

DOE (U.S. Department of Energy), 1989. Technical Approach Document, UMTRADOE/AL-050425.0002, prepared by the U.S. Department of Energy, UMTRA Project Office, Albuquerque Operations Office, Albuquerque, New Mexico, 1989.

JEG (Jacobs Engineering Group, Inc.) n.d., Albuquerque Operations Manual, standard operating procedures, prepared by Jacobs Engineering Group, Inc., Albuquerque, New Mexico, for the U.S. Department of Energy, UMTRA Project Office, Albuquerque Operations Office, Albuquerque, New Mexico.

\section{CODE OF FEDERAL REGULATIONS}

40 CFR Part 192, Health and Environmental Protection Standards for Uranium and Thorium Mill Tailings, U.S. Environmental Protection Agency (1994). 


\section{FEDERAL REGISTER}

60 FR 2854, Groundwater Standards for Remedial Action at Inactive Uranium Processing Sites, Final Rule, U.S. Environmental Protection Agency, 11 January 1995. 
Figure 1

Locations of Monitor Wells and Lysymeters

Maybell, Colorado, Site

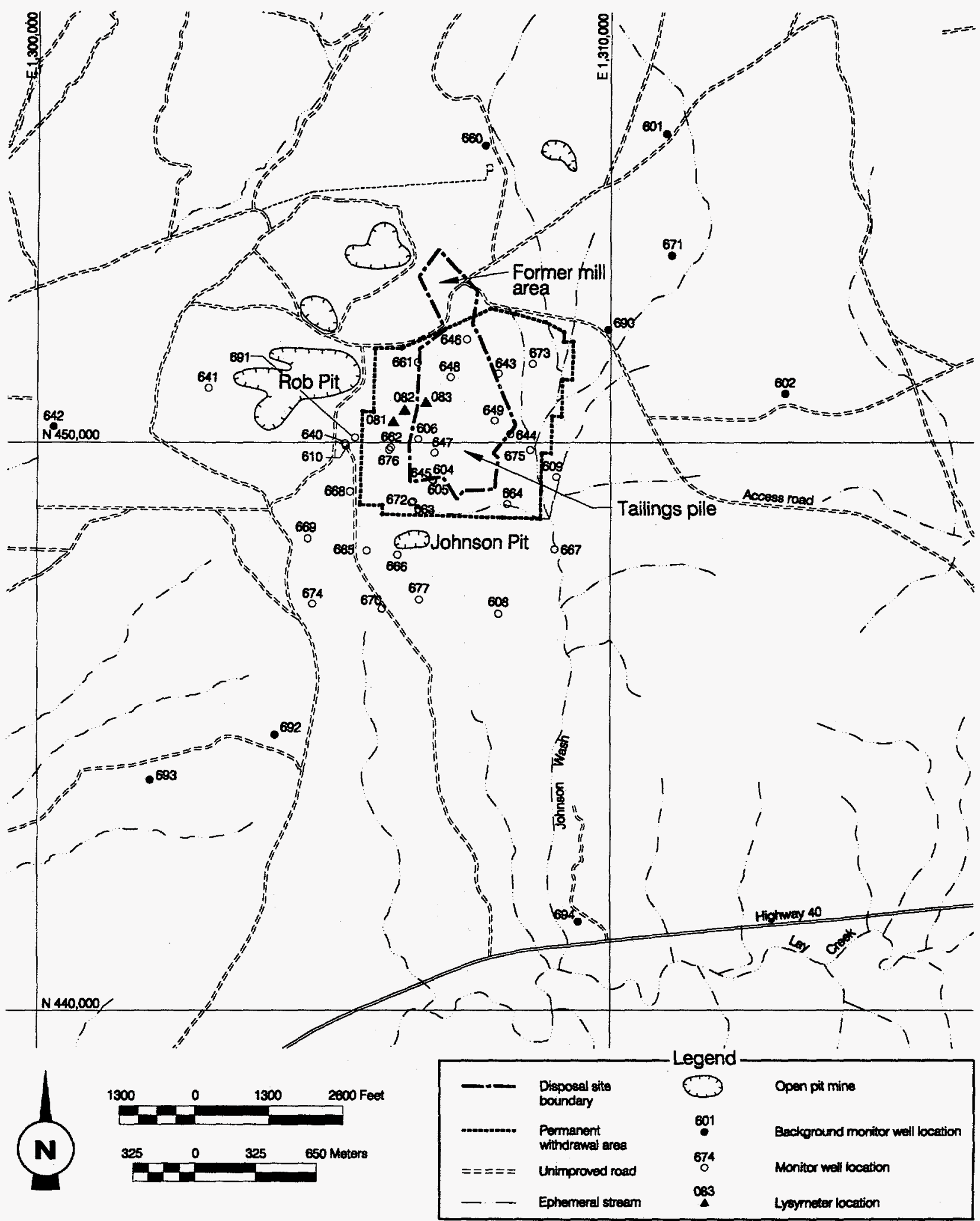

PC: HUSERSSUNGAUAYBELIWSAFUMELLLDWG XFE:MAYEEL DWG O-18-85 
Figure 2

Surface Water Features and Sampling Locations

Maybell, Colorado, Site

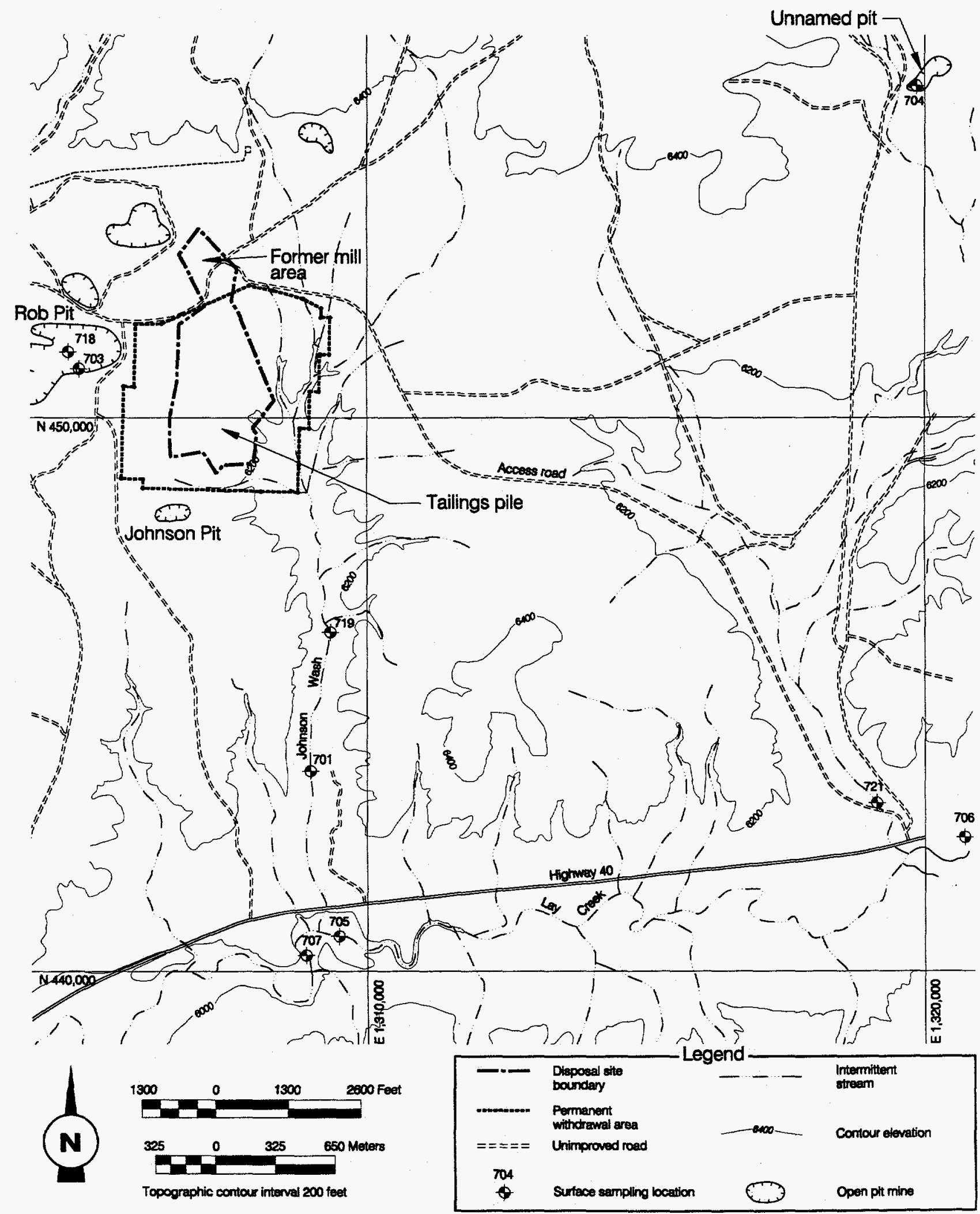

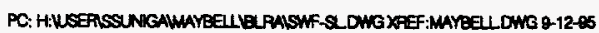

